\title{
Considerações sobre a evolução filogenética do sistema nervoso, o comportamento e a emergência da consciência
}

\author{
Considerations about the nervous system phylogenetic \\ evolution, behavior, and the emergence of \\ consciousness
}

Guilherme Carvalhal Ribas ${ }^{1}$

\begin{abstract}
Resumo
Tendo como base dados de literatura, esta revisão trata dos aspectos genéricos da evolução filogenética do sistema nervoso central, ressaltando em particular o desenvolvimento evolutivo das estruturas encefálicas relacionadas com o comportamento e com as funções cognitivas que vieram caracterizar o ser humano. Sobre as estruturas límbicas, que por ocasião do advento dos mamíferos evolutivamente se desenvolveram sobre o topo do sistema nervoso mais primitivo dos seus ancestrais, o ulterior desenvolvimento cortical com neurônios dispostos em camadas constituiu a base estrutural que viabilizou a discriminação fina das funções sensitivas e sensoriais, a maior complexidade das funções motoras e o desenvolvimento das funções cognitivas e intelectuais que acabaram caracterizando o ser humano. O conhecimento da evolução filogenética do sistema nervoso central nos permite inferir possíveis correlações entre as estruturas encefálicas que se desenvolveram ao longo do processo evolutivo e o comportamento dos seus respectivos seres. Nesta direção, sem se deter em questões de ordem conceitual, a presente revisão termina discutindo possíveis paralelos entre a evolução do sistema nervoso central e a emergência da consciência, à luz das recentes contribuições sobre o assunto.
\end{abstract}

Descritores: Filogenia; Neuroanatomia; Sistema límbico; Manifestações neurocomportamentais; Estado de consciência

\begin{abstract}
This text reviews the generic aspects of the central nervous system evolutionary development, emphasizing the developmental features of the brain structures related with behavior and with the cognitive functions that finally characterized the human being. Over the limbic structures that with the advent of mammals were developed on the top of the primitive nervous system of their ancestrals, the ultimate cortical development with neurons arranged in layers constituted the structural base for an enhanced sensory discrimination, for more complex motor activities, and for the development of cognitive and intellectual functions that finally characterized the human being. The knowledge of the central nervous system phylogeny allow us particularly to infer possible correlations between the brain structures that were developed along phylogeny and the behavior of their related beings. In this direction, without discussing its conceptual aspects, this review ends with a discussion about the central nervous system evolutionary development and the emergence of consciousness, in the light of its most recent contributions.
\end{abstract}

Descriptors: Phylogeny; Neuroanatomy; Limbic system; Neurobehavioral manifestations; Consciousness

1 Departamento de Cirurgia, Faculdade de Medicina, Universidade de São Paulo (USP), São Paulo (SP), Brasil

Financiamento: Inexistente Conflito de interesses: Inexistente

Submetido: 19 Maio 2006

Aceito: 31 Julho 2006

\section{Correspondência}

Guilherme Carvalhal Ribas

Rua Prof. Eduardo Monteiro, 567

05614-120 São Paulo, SP, Brasil

Fax: (55 11) 3744-5063 / 3747-3508

E-mail: guilherme@ribas.med.br 


\section{Introdução}

A análise da evolução filogenética do sistema nervoso permite a compreensão da sua morfologia, que sejam inferidas relações entre os desenvolvimentos e interações das estruturas nervosas e os possíveis comportamentos dos seus respectivos seres, e suscita questionamentos sobre a própria noção de fenômenos, como a consciência.

A presente revisão trata da filogênese do sistema nervoso, descrevendo as principais aquisições pertinentes às mais importantes etapas evolutivas, destacando o desenvolvimento das estruturas nervosas relacionadas com os comportamentos dos seus respectivos seres. Para tanto, este artigo se inicia com considerações genéricas sobre a filogênese, continua com comentários sobre os primórdios do sistema nervoso e sobre a sua evolução nos vertebrados mais primitivos, trata a seguir mais pormenorizadamente da sua evolução nos mamíferos em geral e nos primatas em particular e, após breves comentários sobre o possível paralelismo existente entre a filogênese e a ontogênese, encerra-se com considerações pertinentes à evolução da organização do sistema nervoso e à conseqüente emergência da consciência.

\section{A filogênese como ferramenta de estudo da} neuroanatomia do comportamento

Para Sarnat, do ponto de vista anatômico, há três maneiras básicas de se estudar o sistema nervoso central (SNC). ${ }^{1}$ A primeira consiste em estudar a simples disposição espacial das suas estruturas já desenvolvidas, campo de estudo denominado neuroanatomia; a segunda, em estudar o seu desenvolvimento ontogenético*; e a terceira, em estudar o seu desenvolvimento filogenético ${ }^{\dagger}$ - ocorrido ao longo da chamada evolução das espécies -, o que é feito principalmente através da paleontologia ${ }^{\ddagger}$ e da anatomia comparada. ${ }^{\S}$

Para a discussão de considerações de ordem anatômica pertinentes a questões comportamentais, paralelamente às relevantes contribuições experimentais em animais e às observações clínicas em seres humanos, a análise dos conhecimentos existentes sobre a evolução filogenética das estruturas nervosas nos parece ser particularmente útil, uma vez que ela nos possibilita fazer especulações sobre o aparecimento, o desenvolvimento e o embricamento dessas estruturas e as possíveis características e comportamentos dos seus respectivos elementos evolutivos. Ao propiciar uma visão progressiva das complexidades nervosa e comportamental ao longo da evolução, a análise filogenética também acarreta, a cada passo, questionamentos sobre a própria conceituação de termos como consciência e psiquismo, entre outros, principalmente por propiciar especulações sobre os possíveis paralelos comportamentais existentes entre as diferentes espécies e o próprio ser humano.

Em relação ao processo evolutivo, é importante lembrar que este diz respeito a mudanças que ocorreram por força de fatores principalmente ambientais que influenciaram todos os seres vivos, e não através de simples adições terminais de novas estruturas. Os processos evolutivos têm como principais denominadores comuns a adaptação, a expansão da diversidade e o aumento da complexidade..$^{2-5}$
Do ponto de vista evolutivo, o que nós, seres humanos, temos em comum com outros animais é apenas o fato de que nos originamos de elementos ancestrais comuns hoje extintos e que deram origem a diferentes espécies que, por sua vez, sofreram as suas próprias evoluções. ${ }^{2-3}$ Enquanto, por exemplo, os vertebrados mais primitivos não possuíam qualquer córtex, hoje mesmo os animais menos complexos apresentam algum manto cortical, uma vez que eles também são produtos de uma longa evolução; portanto, o que mais distingue o cérebro humano não é a simples existência da nossa chamada camada neocortical, mas sim a sua dimensão e, principalmente, a sua organização. ${ }^{1,6-9}$ Ao longo de miIhões de anos, o SNC dos vertebrados se desenvolveu até atingir a complexidade do SNC humano, e é particularmente interessante e intrigante como o desenvolvimento embrionário e fetal ${ }^{* *}$ do SNC humano refaz grosseiramente este mesmo curso, conforme será discutido adiante. ${ }^{10-11}$

As maiores dificuldades dos estudos filogenéticos evidentemente se devem à escassez de informações sobre os elementos já extintos, ao longo tempo necessário para observação de quaisquer mudanças evolutivas naturais ou experimentais e à veracidade das inferências sugeridas pelos estudos de anatomia comparada. O desenvolvimento de técnicas de seqüenciamento do DNA seguramente propiciará avanços neste campo, dadas as suas possibilidades de comparar genomas de diferentes espécies e mesmo de espécies extintas.

\section{Considerações sobre a evolução filogenética inicial do SNC}

Os primeiros seres vivos foram organismos unicelulares, sendo que o seu fóssil mais antigo até hoje conhecido foi denominado Eobactéria e data de aproximadamente 3,4 biIhões de anos. O nível de organização a seguir atingido pelas chamadas células eucarióticas as tornou capazes de se dividir e se reproduzir; a ocorrência de mecanismos de simbiose fez surgir os primeiros organismos multicelulares há cerca de 700 milhões de anos. Esses organismos logo invadiram o meio marinho, onde encontraram condições mais estáveis para a sua evolução, vindo a dar origem a peixes primitivos com esqueletos mineralizados há aproximadamente 570 milhões de anos. . $^{2-3,8,12}$

Desde os seres vivos mais primitivos, a principal função do sistema nervoso é propiciar a adaptação ao meio ambiente e, para tanto, se fazem necessárias três propriedades importantes: irritabilidade, condutibilidade e contratilidade. Assim, um ser unicelular, como uma ameba, ao ser estimulado, afasta-se de onde foi tocado, evidenciando que o sistema nervoso nestes seres vivos corresponde às próprias estruturas da sua superfície. .,13-14 $^{1,1}$

Com a evolução dos seres vivos, as suas funções evidentemente foram se tornando mais complexas, surgindo células especializadas para cada função e desenvolvendo-se uma orquestrada coordenação entre o controle da vida de relação com o meio externo e o próprio controle da economia interna destes organismos.

Nas esponjas, os receptores de superfície passaram a trans-

\footnotetext{
"Ontogenia: estudo do desenvolvimento do indivíduo desde a fecundação até a maturidade para a reprodução.

†Filogenia: estudo das relações existentes entre as diferentes espécies de vertebrados no que diz respeito às suas localizações no processo de evolução das espécies.

¥Paleontologia: estudo das espécies já extintas.

${ }^{\S}$ Anatomia comparada: estudo das diferenças anatômicas entre as diferentes espécies existentes.

**O período embrionário estende-se da fecundação até a $8^{a}$ semana, e o período fetal da $8^{a}$ semana até o nascimento.
} 
formar os diferentes estímulos físicos e químicos em impulsos nervosos, como verdadeiros órgãos de sensibilidade, e os músculos e glândulas se desenvolveram como órgãos efetores. ${ }^{3,8}$ Nos metazoários mais diferenciados, as células musculares passaram a se localizar mais profundamente e, nas suas superfícies, as células se diferenciaram para discriminar os diferentes estímulos do meio ambiente. Nos celenterados, as células especializadas em irritabilidade e condutibilidade passaram a se caracterizar como células nervosas propriamente ditas. Nas anêmonas do mar já existem células nervosas unipolares com prolongamentos que fazem contato com as células musculares situadas profundamente. Admite-se, assim, que redes de neurônios propriamente ditos tenham surgido há cerca de 700 milhões de anos em seres marinhos ainda invertebrados. ${ }^{15}$

Paralelamente ao aprofundamento dos músculos e ao desenvolvimento de diferentes receptores sensitivos, nos platelmintos $^{\dagger \dagger}$ e anelídios ${ }^{\ddagger}$ o sistema de coordenação, antes difuso, passa também a se agrupar, caracterizando a centralização do sistema nervoso. Esta centralização aparentemente foi conseqüente às forças da seleção natural, dada a maior vulnerabilidade das estruturas superficiais e a necessidade de coordenação de respostas mais complexas. ${ }^{3,13}$

Nos anelídeos, além do neurônio sensitivo, já se encontram desenvolvidos neurônios eferentes, cujos axônios se ligam ao músculo e desencadeiam a resposta motora. A conexão do neurônio sensitivo como o neurônio motor se faz através de sinapse, caracterizando-se, assim, os elementos básicos de um arco reflexo simples, segmentar. O elemento mais simples que possui um sistema nervoso básico, porém completo, é a hidra. Ao contrário das esponjas, que são seres vivos que não se movimentam, a hidra já se locomove. O seu corpo é constituído por uma camada externa (ectoderma) principalmente sensitiva, por uma camada interna (endoderma) responsável pelos processos de digestão e de eliminação de detritos alimentares e por uma fina camada intermediária (mesoderma). ${ }^{13}$

Em seguida evolutivamente, apareceram os neurônios de associação, que passaram a viabilizar a interação de um segmento com outro: o axônio do neurônio sensitivo passou a fazer sinapse com o neurônio de associação que, por sua vez, ao fazer sinapse com o neurônio motor do segmento vizinho, viabilizou o arco reflexo intersegmentar. O conhecimento das conexões dos neurônios do sistema nervoso da minhoca, por exemplo, já nos permite entender algumas das conexões da medula espinhal dos vertebrados. , $^{1,13}$

A integração anatômica dos níveis segmentares e dos neurônios de associação intersegmentares passou a constituir a medula espinhal e, no seu topo, desenvolveram-se centros nervosos que controlam o funcionamento do corpo e as suas reações ao meio externo. Esses agrupamentos neuronais desenvolvidos no topo medular passaram a constituir os equivalentes dos futuros tronco encefálico e do hipotálamo e, em conjunto com a medula, compuseram o SNC mais básico e comum a todas as espécies e já existente nos primeiros animais vertebrados, ${ }^{\S \S}$ que foram os peixes mais primitivos que surgiram há cerca de 400 milhões de anos..$^{1,3}$

Agregados neuronais dispostos centralmente e ao longo das porções mais superiores do segmento correspondente ao tronco encefálico vieram constituir a chamada formação reticular, que nos elementos mais primitivos é, principalmente, responsável por regulações posturais através de influências retículoespinais e pelo controle de funções orgânicas em conjunção com o hipotálamo. Posteriormente, com o desenvolvimento de estruturas nervosas mais superiores, a formação reticular veio a ser também responsável pelo ciclo sono-vigília e por mecanismos relacionados com a atenção por meio da atuação do chamado sistema reticular ativador ascendente. ${ }^{13,16-18}$

O conglomerado celular no hipotálamo provavelmente corresponde à porção filogeneticamente mais antiga do encéfalo e, desde os seus primórdios, exerceu o controle interno dos diferentes organismos através da sua atividade neurosecretória, sendo responsável pelo controle do metabolismo da água e eletrólitos, da termorregulação, do sistema nervoso autônomo, do apetite e pelo controle endócrino propriamente dito já nos vertebrados mais primitivos. Nestes, a proeminência hipotalâmica basal, denominada tuber cinereum, que abriga os neurônios cujos axônios constituem a haste hipofisária, constitui a maior parte do hipotálamo. ${ }^{1}$

Os elementos primordiais do cerebelo e dos tratos espinocerebelares também começam a se mostrar mais evidentes nos peixes primitivos, principalmente à medida que estes desenvolvem as suas musculaturas do tronco. O corpo constituído por estes conglomerados celulares cerebelares primitivos equivale ao vermis dos vertebrados mais evoluídos. ${ }^{1}$

Sobre esta constituição básica e fundamentalmente segmentar do SNC dos primeiros vertebrados, as forças evolutivas desencadearam a continuidade do desenvolvimento nervoso em função dos eventos a que estes elementos e os seus descendentes vieram a ser submetidos. Entre estes eventos, destacam-se a incursão terrestre que estes seres marinhos vieram a efetuar e o ulterior desenvolvimento dos mamíferos. que culminou com o surgimento dos primatas e do ser humano. . $^{3,8-9}$

\section{O desenvolvimento neural decorrente do advento dos anfíbios e répteis}

As primeiras plantas começaram a cobrir os continentes ainda desertos há cerca de 400 milhões de anos. Elementos marinhos evoluíram vindo a constituir os anfíbios e répteis primitivos, que então ousaram sair do mar há aproximadamente 350 milhões de anos. ${ }^{3}$ Sair do oceano constituiu para esses elementos um desafio de enormes proporções, uma vez que requereu grandes mudanças necessárias principalmente para vencer o seu próprio peso, evitar a perda excessiva de líquidos e mudar a maneira de respirar, o que causou o desenvolvimento de novos modos de reprodução e de novas maneiras de perceber e de se relacionar com o mundo externo.

Entre as várias mudanças desencadeadas pelas novas incursões terrestres, as forças evolutivas causaram no sistema nervoso o desenvolvimento progressivo dos lobos olfatórios, que fizeram do olfato a primeira modalidade sensorial de percepção do mundo externo. Concomitantemente, os desenvolvimentos dos primórdios das estruturas que vieram a originar o complexo amigdalóide e o hipocampo, em embricada conjunção com o hipotálamo, vieram tornar o comportamento

\footnotetext{
${ }^{\dagger}$ Ramo de vermes achatados dorsoventralmente, hermafroditas, que compreende parasitas como as tênias e os esquistossomos.

¥:Ramo de invertebrados que compreende animais de forma alongada e corpo segmentado, sendo os seus principais representantes as minhocas. ${ }^{\$}$ Os animais com medulas nervosas compõem o filo dos cordados e os que possuem vértebras pertencem ao subfilo dos vertebrados e os sanguessugas.
} 
destas novas espécies mais complexo e mais sofisticado. ${ }^{1}$ Por se disporem em torno do topo do segmento que constituía o SNC mais primitivo, essas estruturas foram denominados "estruturas límbicas", uma vez que Limbus, em latim, significa anel. A amígdala (Gr. - amêndoa) e o hipocampo (Gr. - cavalo-marinho) receberam estes nomes pelas suas conformações finais. ${ }^{19-20}$

Enquanto que nos anfíbios o hipocampo é ainda muito rudimentar, correspondendo somente à porção mais dorsomedial da parte mais anterior do seu cérebro, nos répteis já surge o seu aspecto laminar cortical mais primitivo e denominado de arquicórtex. ${ }^{1,21-22}$

As amígdalas se formam através da confluência de vários núcleos ao longo da filogênese. ${ }^{1}$ Situadas anteriormente a cada hipocampo já nos animais mais primitivos, recebem basicamente eferências olfatórias e se relacionam principalmente com os próprios hipocampos e com o hipotálamo. ${ }^{13,21}$

Dado o surgimento imbricado das estruturas olfatórias, hipocampais e do complexo amigdalóide, a primeira modalidade de memória adquirida pelos vertebrados mais primitivos foi a memória olfativa, que veio permitir que esses animais pudessem assim identificar nutrientes, elementos venenosos, parceiros sexuais, presas e predadores. Enquanto uma camada de células desse córtex primitivo passou a possibilitar a identificação e a categorização do cheiro, a atuação de uma segunda camada de células passou a desencadear o comportamento apropriado àquela situação, portanto um comportamento já "inteligente" e não automático. Por sua vez, as conexões existentes entre as mencionadas estruturas límbicas e o hipotálamo, principal coordenador da vida vegetativa, propiciaram o desenvolvimento de sensações básicas como a saciedade, o desejo sexual e o medo, que então constituíram os primórdios da vida emocional. Do ponto de vista biológico e comportamental, é interessante aqui ressaltar que o ato de copular aparece pela primeira vez ao longo da evolução com os répteis, ${ }^{3}$ constituindo, portanto, um fenômeno intrinsecamente relacionado com estas mesmas estruturas límbicas e neurovegetativas.

\section{O desenvolvimento encefálico dos mamíferos}

Os hipocampos e as estruturas que com eles se desenvolveram com a evolução dos mamíferos - entre as quais se destacam os fórnices e as áreas corticais adjacentes -, são denominados conjunto de formação hipocampal ${ }^{13,20-21,23}$ e, do ponto de vista funcional, tornaram-se os responsáveis pela aquisição da capacidade de armazenar informações, viabilizando, portanto, o que se conceitua como memória e aprendizado.

Nos mamíferos menos evoluídos, o hipocampo ainda ocupa uma posição dorsal ao longo de cada parede medial dos hemisférios cerebrais e apenas com o posterior desenvolvimento do neocórtex e do corpo caloso é que os hipocampos vieram a ser deslocados posterior, inferior e lateralmente. ${ }^{1}$ Este deslocamento hipocampal póstero-inferior que ocorre em torno do tálamo é que origina as caracterizações anatômicas do fórnix sob o corpo caloso e do indúsio cinzento sobre o corpo caloso, que constituem, portanto, verdadeiros prolongamentos do hipocampo. Com este deslocamento do hipocampo, o espaço entre o fórnix e o tálamo passa a constituir a fissura corióidea. ${ }^{18,21,24}$

É interessante ressaltar que esse córtex hipocampal mais primitivo possui uma substância branca correspondente situada externamente, de maneira equivalente à disposição da substância branca da medula e do tronco cerebral, e que este arranjo persiste durante toda a evolução, inclusive no homem, com o hipocampo coberto pelo chamado alveus, que é, portanto, constituído pelos axônios que originam a fímbria do fórnix. O grande desenvolvimento ulterior do neocórtex e do corpo caloso, que ocorre de forma a encobrir as vesículas ou ventrículos telencefálicos, acaba fazendo com que os hipocampos situados nas suas paredes mesiais passem a ser as únicas superfícies corticais intraventriculares.

As amígdalas, que por sua vez se relacionam funcionalmente com a gênese das emoções (que nos animais primitivos dizem respeito basicamente às reações do tipo de alerta, de fuga e vegetativas e que visam fundamentalmente a sobrevivência e a manutenção da espécie), desde os seus primórdios se relacionam topográfica e funcionalmente com as estruturas ipsolaterais que compõem cada formação hipocampal. Por ocasião do ulterior desenvolvimento do neocórtex, desenvolvem-se inter-relações principalmente entre as amígdalas e as porções mais anteriores dos hemisférios cerebrais. ${ }^{17,21,25}$

Com o desenvolvimento do neocórtex dos mamíferos, há cerca de 230 milhões de anos, o progressivo aumento do número e da complexidade dos estímulos sensitivos gerais (sensibilidade táctil, térmica, dolorosa e profunda) e sensoriais (gustação, audição e principalmente visão), que passaram a ser processados pelo SNC, requereu também o desenvolvimento de uma estrutura receptora e integradora de todas estas eferências. Os conglomerados de núcleos desenvolvidos na base de cada hemisfério cerebral para este fim vieram a constituir os tálamos (Gr. - câmara interna, provavelmente por constituir, de cada lado, parte da parede lateral da cavidade central que é o III ventrículo), ${ }^{22}$ que então se situaram sobre o topo do sistema nervoso já pré-existente. Por acabar se situando inferiormente a ambos os tálamos, a região que alberga os núcleos responsáveis principalmente pela vida vegetativa e controle neuroendocrinológico é, portanto, justificadamente denominada de hipotálamo.

O desenvolvimento evolutivo dos tálamos ocorreu concomitante com o dos hemisférios cerebrais, dadas as estreitas inter-relações destas estruturas, com os tálamos vindo a se caracterizar como conglomerados de centros receptores e integradores de estímulos aferentes e as estruturas hemisféricas cerebrais como centros de coordenação e de discriminação. As numerosas inter-relações existentes entre os tálamos e o córtex dos hemisférios cerebrais, constituídas principalmente pelas projeções talâmicas, geram uma situação de interdependência entre o diencéfalo e o telencéfalo que se reflete praticamente sobre todas as funções corticais. ${ }^{13,17,21}$

Apesar do tálamo a princípio se constituir primariamente como sendo um grande centro receptor, o fato dessa estrutura já receber as informações de forma discriminada por meio de vias específicas e que terminam em núcleos talâmicos distintos já possibilita que ocorram percepções também já em parte discriminadas em nível subcortical, deixando para o córtex a execução de um papel mais analítico, modulador e integrador com outras áreas corticais. ${ }^{13,17,21,23}$ É interessante ressaltar que a única via aferente que se projeta diretamente sobre o córtex sem passar pelo tálamo é a que veicula a olfação, uma vez que esta modalidade sensorial é filogeneticamente bem mais antiga do que as estruturas talâmicas e hemisféricas.

Enquanto os primitivos anfíbios não possuíam qualquer elemento hemisférico telencefálico bem desenvolvido, os répteis já apresentavam os já mencionados lobos olfativos, hipocampos, amígdalas e septum, constituído pelos núcleos septais. Além 
destas, as outras estruturas telencefálicas mais primitivas são os corpos estriados de cada hemisfério, que são particularmente relacionados com as funções motoras. ${ }^{1}$

Do ponto de vista morfológico, a progressiva incorporação de novas estruturas e o estabelecimento de novas conexões se fizeram de maneira a não acarretar um aumento exagerado de volume e, para tanto, as estruturas axiais mais primitivas do SNC foram sendo dobradas sobre si mesmas originando flexuras, e as estruturas mais novas foram também se curvando de maneiras variadas e de forma a envolver as anteriores. Este processo, que visou principalmente otimizar a disposição espacial dos diversos componentes do SNC ao longo da evolução, é o responsável pela conformação final do SNC no ser humano, e explica porque muitas das estruturas telencefálicas profundas e superficiais se dispõem em forma de "C" em torno do seu centro constituído por ambos os tálamos que se encontram dispostos no topo do tronco encefálico. 1,18,24,26

O corpo estriado, que se dispunha como uma massa única de cada lado do topo do tronco encefálico dos seres mais primitivos, foi evolutivamente dividido ao meio pelas conexões tálamo-corticais e pelas fibras de projeção originadas no córtex e advindas do desenvolvimento do neocórtex nos mamíferos. Isso deu origem ao núcleo caudado medialmente e putame lateralmente, separados, portanto, pela cápsula interna. ${ }^{1}$ Do ponto de vista evolutivo, a amígdala é denominada de arquiestriado, o globo pálido de paleoestriado e o núcleo caudado e o putame de neoestriado. ${ }^{22}$

Em relação à superfície cerebral, estudos de citoarquitetura sugerem que o seu desenvolvimento ocorreu conforme uma determinada organização topográfica. Os córtices mais antigos, constituídos pelo arquicórtex (hipocampo) e pelo paleocórtex (córtex piriforme ou olfatório) dos répteis primitivos, originaram ao seu redor um córtex intermediário que, a seguir, gerou um primeiro anel concêntrico constituído por um córtex mais diferenciado (seis camadas). Este, ao se desenvolver, originou as estruturas parahipocampais da face medial dos hemisférios (giros paraterminal, paraolfatório, do cíngulo e parahipocampal) e o córtex insular lateralmente. Posteriormente, desenvolveu-se em cada hemisfério um outro anel lateral (constituído pelo neocórtex mais diferenciado), que originou as áreas corticais paralímbicas e parainsulares constituídas pelos córtices especializados (córtex motor, sensitivo, auditivo e visual). , $18,22^{2}$

Dada a constituição trilaminar do arquicórtex e a constituição já com seis camadas - mas ainda mal caracterizadas - do paleocórtex, ambos são atualmente denominados de alocórtex, em contraposição ao neocórtex constituído por seis camadas bem distintas, que é denominado de isocórtex. Apesar de também já possuir seis camadas, o córtex das áreas adjacentes ao hipocampo e o córtex da ínsula são também denominados de mesocórtex, por terem uma citoarquitetura intermediária entre 0 arquicórtex e o neocórtex ${ }^{1,13,18,21-22,27-29}$

Do ponto de vista anatômico, o derradeiro desenvolvimento cortical se fez através da ocorrência de progressivas invaginações e dobraduras da superfície cerebral ao longo de toda a sua extensão, gerando, assim, os seus sulcos e fissuras. Esse processo visou fundamentalmente a expansão da superfície cerebral sem que houvesse um aumento proporcional do seu volume cerebral e acabou sendo o principal responsável pela morfologia final da superfície cerebral humana, tipicamente caracterizada pelos seus giros ou cincunvoluções dispostas entre os seus sulcos e fissuras. A eficiência deste pro-
Tabela 1 - Desenvolvimento cortical dos mamíferos

\begin{tabular}{|c|c|c|}
\hline Córtex primitivo & Anel cortical medial & Anel cortical lateral \\
\hline ALOCÓRTEX & \multicolumn{2}{|c|}{ ISOCÓRTEX } \\
\hline $\begin{array}{l}\text { Estruturas límbicas } \\
\text { primitivas }\end{array}$ & $\begin{array}{l}\text { Estruturas } \\
\text { parahipocampais e insula }\end{array}$ & $\begin{array}{l}\text { Estruturas paralimbicas } \\
\text { e parainsulares }\end{array}$ \\
\hline Arquicórtex & Mesocórtex & Neocórtex \\
\hline Hipocampo & $\begin{array}{l}\text { Giro parahipocampal } \\
\text { Giro do cíngulo } \\
\text { Giro paraterminal }\end{array}$ & $\begin{array}{l}\text { Córtex motor } \\
\text { Córtex sensitivo } \\
\text { Córtex visual }\end{array}$ \\
\hline $\begin{array}{l}\text { Paleocórtex } \\
\text { Córtex olfatório } \\
\text { ou piriforme }\end{array}$ & $\begin{array}{l}\text { Córtex orbital posterior } \\
\text { Ínsula }\end{array}$ & $\begin{array}{l}\text { Córtex auditivo } \\
\text { Córtex de linguagem } \\
\text { (humanos) }\end{array}$ \\
\hline
\end{tabular}

cesso poupador de espaço pode ser apreciada pela observação do fato de que, considerando a fissura inter-hemisférica, cerca de dois terços da superfície cortical humana se encontram como que soterradas nos seus sulcos e fissuras, dispondo-se, então, como áreas que se confrontam no interior destas depressões e que se continuam ao longo dos seus bojos. ${ }^{18,29}$

Definem-se como sulcos os espaços que separam e que delimitam os giros cerebrais. Quando pronunciados e anatomicamente constantes, os sulcos são denominados de fissuras. Dada a anatomia das meninges que recobrem o SNC, os sulcos e fissuras constituem expansões do espaço subaracnóideo. ${ }^{29-30}$

Ao longo da evolução, os animais podem ser classificados em lisencéfalos e em girencéfalos conforme possuam o pallium ou o manto cerebral liso (como os répteis e as aves), ou já apresentem sulcos delimitando giros, o que se inicia com o advento dos mamíferos. Os primeiros sulcos que surgem na superfície cerebral ao longo da filogênese são os sulcos hipocampal e rinal. 1,18

Evolutivamente, o sulco hipocampal surge em função do deslocamento ínfero-lateral do hipocampo e acaba delimitando o aspecto mais medial desta estrutura do subiculum, que já é parte do giro hipocampal. Uma vez que o hipocampo é uma estrutura constituída por arquicórtex e o subiculum por paleocórtex, o sulco hipocampal, portanto, delimita estas duas áreas corticais mais primitivas. ${ }^{1}$

O sulco rinal, por sua vez, surge como decorrência do deslocamento ventral da área olfatória lateral, ou córtex piriforme, causado pelo desenvolvimento do neocórtex temporal adjacente. Como a área olfatória lateral é constituída por paleocórtex, o sulco rinal então delimita o paleocórtex do neocórtex. ${ }^{1}$

A fissura lateral ou silviana surge evolutivamente de forma sui generis, no sentido em que ela constitui o único sulco cerebral que não é decorrente apenas de um processo de invaginação, sendo também devida a um fenômeno de justaposição de duas superfícies cerebrais. Esta ocorrência evolutiva se deve aos progressivos desenvolvimentos das porções frontais dorso-laterais e da porção superior do lobo temporal, que acabam por encobrir o mais antigo córtex insular de cada hemisfério, constituindo, acima desta, a fissura silviana que abriga a cisterna silviana. ${ }^{1,18,29-30}$ As porções cerebrais que assim encobrem as ínsulas são denominadas de operculares (do latim: cortinas) frontais e temporais. ${ }^{19,22}$

A fissura silviana - que separa os lobos frontal e temporal e o sulco central ou de Rolando - que separa os giros pré e pós-centrais -, já se encontram presentes nos primeiros primatas. Os antropóides, como o orangotango, o chimpanzé e o gorila, já possuem uma disposição sulcal relativamente semelhante à do homem, sendo que as suas maiores diferen- 
ças residem na anatomia dos sulcos frontais que se desenvolvem mais marcadamente por ocasião da caracterização do córtex humano. No entanto, é importante também mencionar que a complexidade do seu padrão não é por si unicamente responsável pela maior diferenciação do córtex humano, uma vez que outros animais, como os elefantes e as baleias, além de possuírem encéfalos maiores, também exibem maior complexidade das suas disposições de sulcos e giros. 1,9,31

Concomitantemente com o crescimento do neocórtex, desenvolveu-se um volumoso e intricado contigente de fibras constituídas principalmente pelos axônios dos seus neurônios e pelos axônios que se originam nos tálamos e que se dirigem para as diversas áreas corticais, denominadas "radiações talâmicas".

Este universo de feixes e tratos tem como finalidade conectar os diferentes centros e núcleos nervosos entre si, e é composto basicamente por dois contingentes de fibras. O primeiro, denominado de fibras de projeção, é composto por fibras que se originam no córtex e que se dirigem para centros nervosos mais inferiores (entre as quais se destacam as fibras relacionadas com a motricidade), e pelas radiações talâmicas (sensitivas e sensoriais). Ao convergirem centralmente, as fibras de projeção constituem a chamada cápsula interna. O segundo contigente é formado pelas fibras de associação, que se subdividem em intra-hemisféricas e inter-hemisféricas, estas últimas também denominadas de comissuras, das quais a mais importante é o corpo caloso. ${ }^{13,17-18,21,24}$

Dadas as suas importâncias funcionais, cabe aqui também destacar as fibras que constituem o sistema reticular ativador ascendente e o feixe prosencefálico medial. As fibras que compõem o sistema reticular ativador ascendente se originam nos núcleos da formação reticular ponto-mesencefálica, projetamse em ambos os hemisférios cerebrais por meio do tálamo e por vias extra-talâmicas, e são responsáveis pelo ciclo sonovigília e por mecanismos relacionados com atenção. 0 feixe prosecenfálico medial, por sua vez, se dispõe entre os núcleos septais, núcleos hipotalâmicos e núcleo interpeduncular do mesencéfalo, constituindo a principal via de ligação entre as estruturas límbicas e a formação reticular, veiculando basicamente estímulos viscerais. ${ }^{16-18,21}$

Considerações sobre a evolução cerebral dos primatas

O grande desenvolvimento do SNC que ocorreu durante a evolução dos vertebrados e dos mamíferos em particular, com o advento do neocórtex se fez de maneira marcadamente desproporcional em relação ao desenvolvimento do restante do corpo destes animais, caracterizando um fenômeno evolutivo denominado "encefalização".1,9,32-34 Segundo a teoria evolucionista, tanto o aumento do volume encefálico quanto a especialização progressiva das suas estruturas ocorreram em função das forças evolutivas ambientais e como conseqüência do próprio desenvolvimento de novas capacidades. 8,31,33

Os primeiros primatas, denominados Ramapithecus, surgiram no continente africano há 50 milhões de anos, e há cerca de 13 milhões de anos vários séculos de estiagem tornaram o clima das florestas mais seco, fazendo com que alguns destes primatas primitivos saíssem das florestas em direção às savanas. Os primatas que permaneceram nas florestas evoluíram como chimpanzés, gorilas e orangotangos, enquanto os que saíram deram origem aos nossos ancestrais. ${ }^{3,33}$ Pro- gressivamente, estes últimos passaram a andar de forma ereta, o que liberou as mãos para a execução de manipulações mais complexas e acarretou o desenvolvimento da função visual em detrimento da olfação, que então involuiu gradativamente. Esses fenômenos evidentemente foram acompanhados não só de alterações corpóreas específicas, mas também do desenvolvimento particular de áreas neocorticais especializadas para estes fins. 3,9,31,33

Em relação à visão, em particular, enquanto os animais que possuem os olhos posicionados lateralmente enxergam campos visuais diferentes com uma pequena superposição central que propicia a simples continuidade de ambas as visões, o alinhamento das órbitas que se desenvolveu nos primatas passou a possibilitar a visualização de um mesmo campo visual a partir de dois pontos de vista ligeiramente diferentes. A integração neural destas duas imagens veio proporcionar a percepção de profundidade, que caracteriza a chamada visão tridimensional ou estereoscópica. Esta significativa evolução visual proporcionou uma percepção bem mais apurada do meio ambiente e ocorreu à custa de um grande desenvolvimento do córtex visual e das vias de associação visual, o que é anatomicamente refletido pelo maior volume dos pólos occipitais e pelas grandes dimensões das porções posteriores do corpo caloso. 8,9,35

Os hominídeos mais antigos conhecidos são os membros do gênero Australopithecus, ou macacos meridionais, que surgiram há cerca de 4 milhões de anos. O fóssil correspondente mais antigo que foi encontrado é conhecido como Lucy e é um membro da espécie Australopithecus Afarensis, assim denominada por ser oriunda de uma região da Etiópia conhecida como Afar. Estes primeiros hominídeos já caminhavam eretos, tinham aproximadamente $1,40 \mathrm{~m}$ de altura, já viviam em grupos sociais e, muito provavelmente, eram cobertos de pêlos como os chimpanzés modernos. Os seus cérebros possuíam volume de aproximadamente $400 \mathrm{~cm}^{3}$, equivalente ao tamanho dos cérebros dos chimpanzés adultos modernos e de humanos recém-nascidos. ${ }^{3,7-9,33-34}$

Os primeiros membros do gênero Homo*** surgiram há aproximadamente 2 milhões de anos. O chamado Homo habilis, já capaz de fabricar instrumentos e ferramentas simples, durou apenas cerca de 500 anos e o seu sucessor, Homo erectus, aprendeu a controlar o fogo, espalhou-se pelo mundo a partir da África, e durou cerca de 1,5 milhão de anos. Os volumes dos seus cérebros variavam de 700 a $1.200 \mathrm{~cm}^{3}$. 0 homem moderno, ou Homo sapiens, se originou na África entre 150 a 100 mil anos atrás, conforme o registro fóssil de uma muIher, denominada de Eva, que data de 125 mil anos. Com um volume cerebral já de aproximadamente $1.400 \mathrm{~cm}^{3}$, o conhecido fóssil humano denominado Homem de Cro-Magnon, descoberto na França em 1864, data de aproximadamente 80.000 anos e corresponde ao gênero que povoou a Europa. A denominação Homo sapiens sapiens diz respeito ao homem moderno que evolutivamente data de 50 mil anos. ${ }^{6-7,31,33}$

O chamado Homem de Neanderthal surgiu há 150 mil anos, possuía um tamanho cerebral ligeiramente maior que o dos seres humanos, com cerca de $1.500 \mathrm{~cm}^{3}$, mas a sua duração foi transitória por razões ainda não esclarecidas., 73-34

O fenômeno de encefalização pode ser mensurado objetivamente por meio do chamado "quociente de encefalização",

*** Termo proposto pelo cientista sueco Carlos Lineu (1707-1778), que fez a clássica classificação do reino animal que ficou conhecida como classificação de Lineu. 
que é calculado pela relação existente entre o tamanho real do cérebro e o seu tamanho esperado dado pela média dos mamíferos viventes. Durante o desenvolvimento dos primatas passou a ocorrer concomitantemente um crescimento também francamente mais pronunciado das chamadas áreas préfrontais, o que demonstra a direta relação destas regiões com as funções ditas mais superiores. As porções anteriores dos lobos temporais e os pólos occipitais também são bem mais desenvolvidos no homem, estes últimos devido ao aumento de áreas associativas visuais. 9,31,34,36-37 $^{2}$

Em relação à evolução do seu tamanho propriamente dito, ao longo da evolução dos primatas o encéfalo apresentou um aumento de três a quatro vezes em 6 bilhões de anos. Este aumento se deu mais às custas de conexões do que de neurônios e, sobretudo, com um aumento do índice conexões locais/distantes, o que equivale a um aumento preponderante das conexões de associações intra e inter-hemisféricas cerebrais. 7,9,13,34

Entretanto, entre todos os eventos evolutivos que culminaram com o advento do SNC do homem, sem dúvida o que mais se destaca é a aquisição da linguagem, uma vez que é esta qualidade que tornou possível todo o desenvolvimento da cultura humana, inclusive no sentido real de viabilizar a própria continuação da evolução humana, que deixou de ser biológica e passou a ser cultural.

Evolutivamente, é difícil estabelecer o momento em que surgiu a linguagem, mas as mudanças oronasofaríngeas necessárias para a emissão de sons em particular foram também possibilitadas e desencadeadas pela adoção da postura ereta. ${ }^{1,33}$

As áreas corticais responsáveis pelas funções lingüísticas se desenvolveram em torno da fissura lateral ou silviana do hemisfério, que passou, então, a ser chamado de hemisfério dominante, e que, geralmente, corresponde ao hemisfério cerebral esquerdo. Entre estas áreas corticais, destacam-se uma área mais anterior, denominada "área motora da linguagem" ou "área de Broca", e uma área mais posterior, denominada "área sensitiva da linguagem" ou "área de Wernicke". 17-19,21,23,38

A área motora da linguagem, descrita por Broca ${ }^{\dagger \dagger},{ }^{38-39}$ possui uma localização anatômica relativamente bem determinada dispondo-se nas partes triangular e opercular do giro frontal inferior dominante do ser humano. Viabiliza a palavra falada através das suas conexões diretas com a região do giro motor que desencadeia e coordena a motricidade orofaríngea. A área sensitiva da linguagem, por sua vez, foi descrita por Wernicke ${ }^{\ddagger \ddagger 39}$ e possui uma topografia menos definida, espraiando-se em torno da porção terminal da fissura silviana dominante ao longo dos giros supramarginal, angular e temporal superior. Por meio das suas conexões com a área auditiva primária do opérculo temporal e com áreas occipitais visuais torna possível, respectivamente, a compreensão da palavra falada e a leitura. A existência de conexões entre as áreas de Broca e de Wernicke, que proporcionam o entrosamento da compreensão com a expressão, fazem com que toda a região perisilviana do hemisfério dominante seja relacionada com funções lingüísticas.

As observações de que as crianças de diferentes origens adquirem a linguagem de maneira quase que automática entre os dois e quatro anos, e com seqüências e velocidades também semelhantes, levou os estudiosos do assunto, entre os quais se destaca o lingüista Noam Chomsky, ${ }^{40}$ a acreditar que todas as linguagens humanas compartilham um mesmo conjunto inato de mecanismos equivalentes a regras gramaticais que são geneticamente determinadas, e que estariam como que impressas em circuitos cerebrais humanos. Esta noção pode ser mais bem compreendida pelo comentário de Steven Pinker que, do ponto de vista chomskiano, "se um cientista marciano viesse a visitar a Terra concluiria que, deixando de lado vocábulos ininteligíveis, os terráqueos falam uma única língua". ${ }^{31,35}$ Portanto, paralelamente à organização neurofisiologicamente mais superficial da linguagem falada e escrita, há um conjunto de mecanismos lingüísticos que se organizam em um nível mais profundo e que dizem respeito basicamente a algo como significados puros.

As manifestações evolutivas das diferentes formas de linguagem indiretamente já refletem as capacidades de comunicação e criativas do cérebro humano. Nesse sentido, é interessante destacar que expressões artísticas em forma de pinturas já surgiram há cerca de 30.000 anos, enquanto a escrita teve os seus primórdios há aproximadamente 10.000 anos. ${ }^{9,34-35,41}$ As obras de arte mais primitivas foram descobertas ao longo da faixa do território europeu que se estende da Espanha ao sul da Rússia, e são constituídas principalmente por pinturas em paredes de cavernas feitas por ocasião de uma nova idade do gelo. ${ }^{\S \S}$ As figuras caracterizam principalmente bisões, cavalos, leões e renas, estando geralmente relacionadas com motivos de caças e parecendo ter o propósito de aplacar as forças da natureza da qual as comunidades dependiam. Representações de figuras meio homens meio animais, por sua vez, sugerem a existência de mitos, e foram feitas em épocas em que já se enterravam os mortos com adornos. ${ }^{33,41}$

Descobertas de bastões feitos com ossos ou chifres e ricamente entalhados de forma a caracterizar representações simbólicas, que datam de cerca de 20.000 anos, já sugerem a existência de uma linguagem mais complexa, e os crânios dos seres humanos desta época demonstram conformações compatíveis com um maior desenvolvimento das regiões frontotemporais e da fissura silviana, que abrigam as áreas corticais mais especificamente relacionadas com as funções de linguagem. 7,9,32-22,41

Nos seus primórdios, a escrita dizia respeito à utilização de símbolos que visavam constituir numerações. Os seus primeiros registros, encontrados em montanhas da região dos atuais Irã e Turquia, datam de aproximadamente 12.000 anos e visam quantificar colheitas e rebanhos. No entanto, o conceito de numeração independente de qualificação parece ter surgido há 5.000 anos, na chamada Mesopotâmia, região do moderno Iraque. O equivalente às primeiras linguagens escritas, por sua vez, aparentemente foi desenvolvido entre 10.000 e 6.000 anos atrás e era constituído por minúsculos objetos cerâmicos padronizados encontrados no Oriente Próximo, que representavam diferentes itens e quantidades. ${ }^{41}$

A civilização egípcia, que se iniciou há cerca de 5.000 anos, criou os hieróglifos, que constituem uma escrita ideográfica, portanto representativa e ainda não composta de sons. A escrita egípcia era composta por duas versões, sendo

\footnotetext{
${ }^{\dagger \dagger}$ Pierre Paul Broca (1824-1880) - cirurgião e antropólogo francês que descreveu a afasia motora e introduziu o conceito de localização cerebral.

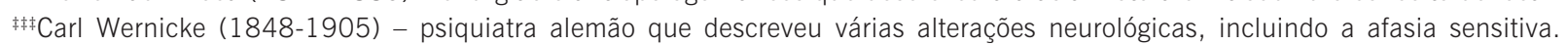

\$§§ Fenômenos glaciais cíclicos que ocorrem com intervalo de milhares de anos.
} 
uma utilizada para textos religiosos e oficiais (hierática) e outra mais popular (demótica), que procurava exprimir conceitos abstratos. A sua difusão foi particularmente possibilitada pelas folhas de papiro, que cresciam profusamente ao longo do Nilo, e pelo comércio também proporcionado por este rio. A escrita cuneiforme dos assírios, contemporâneos dos egípcios, era semelhante no sentido de que se baseava em combinações de símbolos que pareciam pregos ou cunhas - daí o seu nome.

Coube aos fenícios, ao entrarem em contacto principalmente com os egípcios e motivados pelas suas necessidades comerciais, serem os responsáveis pela criação da primeira escrita alfabética, de base fonética. Este alfabeto teve, portanto, influência da escrita egípcia, e se difundiu na ocasião por todo o ocidente, tendo atingido também a Índia e vindo a se constituir como a base de praticamente todos os alfabetos que se seguiram. Posteriormente, os gregos desenvolveram muito a escrita através do alfabeto grego que, por sua vez, deu origem ao alfabeto latino.

Como conseqüência direta, ainda na Grécia, a linguagem desencadeia o início do pensamento moderno. No século VI a.C., nasce a filosofia com os pensadores de Mileto e, mais tarde, após as contribuições de Sócrates e Platão, Aristóteles (384-322 a.C.) estabelece a lógica como método de pensar.

Considerações entre as possíveis correlações entre a filogênese e a ontogênese

A existência de relações entre a filogênese (evolução filogenética das espécies) e a ontogênese (evolução embriológica, fetal e pós-natal do ser humano) constitui uma questão já aventada e discutida desde os tempos da Grécia antiga. Entre os filósofos pré-socráticos, Anaximandro, Anaximenes e Demócritus conceberam o cosmos como se desenvolvendo circundado por um envelope que lembra a membrana amniótica. Anaximandro e Empédocles chegaram a comparar os estágios da embriologia humana com etapas prévias do ciclo cósmico por eles imaginado. Aristóteles (384-322 a.C.), considerado pai da anatomia comparada, ao classificar os animais o fez conforme um critério progressivo de "perfeição". Ele acreditava que, durante o seu desenvolvimento, o embrião humano incorporava "almas" também progressivamente mais diferenciadas, por ele denominadas "nutritiva, sensitiva e racional." 11

No entanto, coube a Ernest Haeckel (1834-1919) formular o conhecido dito de que a "ontogenia recapitula a filogenia", ao afirmar, a partir dos seus estudos, que "a rápida e breve ontogenia é uma sinopse condensada da longa e lenta história da filogênese". ${ }^{10}$ Para Haeckel, cada etapa embriológica se caracterizaria como tendo características semelhantes ao produto adulto final de cada ancestral correspondente àquela etapa, e que teriam sido realocadas nos estágios iniciais do desenvolvimento ontogenético humano por forças decorrentes da evolução da sua linhagem.11 Os chamados recapitulacionistas evolucionários que o seguiram se fundamentaram em dois mecanismos básicos para relacionar a evolução com a embriologia: 1) a lei ou fenômeno de adição terminal, que explica as mudanças evolutivas como ocorrendo pela adição de novas etapas sobre o estágio final de cada respectivo ancestral; e 2) a lei ou fenômeno de condensação, na qual os processos de desenvolvimento evolucionário ocorrem e são acelerados pelo deslocamento de características ancestrais para fases mais precoces do desenvolvimento embrionário dos respectivos descendentes.
Entre os autores que se opuseram às hipóteses de Haeckel, destaca-se o embriologista e antropologista alemão Karl Ernest von Baer (1792-1876), que refutou a concepção de estágios embrionários caracterizados por particularidades ancestrais adultas e sugeriu que estas etapas equivaliam simplesmente a estágios precoces comuns à ontogenia de todos os vertebrados. ${ }^{11}$

Stephen Jay Gould (1941-2002), professor de Zoologia da Universidade de Harvard e grande evolucionista da atualidade, ao tratar das relações entre a filogênese e a ontogênese humana, admite que as mudanças evolutivas se expressam na ontogenia do homem e valoriza, em particular como mecanismo evolutivo, a importância da chamada heterocronia (ou variação temporal do aparecimento de características ontogenéticas) como determinante das mudanças filogenéticas. Portanto, para Gould, as mudanças de regulação dos genes por fim responsáveis pelas mutações evolutivas são, em grande parte, determinadas pelas mudanças dos momentos embriológicos de desenvolvimento de características comuns a ancestrais e descendentes. ${ }^{4,11}$

Em contraposição às dúvidas pertinentes aos paralelos eventualmente existentes entre a filogênese e a ontogênese, a semelhança das conformações apresentadas pelo SNC nas progressivas etapas filogenéticas e embriológico-fetais do ser humano são particularmente evidentes (Figura 1).

Considerações sobre a evolução da organização nervosa e a emergência da consciência

A Tabela 2 e os esquemas da Figura 2 ilustram o progressivo desenvolvimento e a disposição das estruturas encefálicas ao longo do processo evolutivo.

Tendo como base esses conhecimentos evolutivos, McLean, em 1973, propôs a "Teoria do Encéfalo 3 em 1" (Triune Brain), ${ }^{44}$ a qual caracteriza de forma sintética a evolução filogenética do SNC como ocorrendo através de três etapas básicas, por ele denominadas: 1) encéfalo reptiliano (medula e tronco encefálico, com as estruturas olfatórias, amígdala e hipocampo ainda rudimentares); 2) encéfalo do mamífero (desenvolvimento significativo do hipocampo, caracterização do sistema límbico, desenvolvimento inicial do neocórtex); e 3) encéfalo humano (desenvolvimento final do neocórtex, em particular das áreas corticais associativas, e caracterização das áreas de linguagem) (Figura 3), com os seus cerca de 100 bilhões de neurônios que se conectam através de 1.000 e 10.000 sinapses por neurônio.

Para Edelman, o emaranhado de fibras nervosas originadas nos neurônios encefálicos se organiza em três conjuntos de circuitos básicos: o sistema de projeção difusa, o conjunto de sistemas córtico-subcorticais e o sistema tálamo-cortical. ${ }^{6}$

O sistema de projeção difusa se origina no tronco encefálico e no hipotálamo, projeta-se difusamente principalmente sobre o córtex cerebral e também sobre o hipocampo, gânglios da base, cerebelo e medula. Esse sistema se origina em núcleos noradrenérgicos (locus ceruleus), serotoninérgicos (núcleos de rafe) e também em núcleos dopaminérgicos, histaminérgicos e colinérgicos. ${ }^{6,13}$ Compõe o já mencionado sistema reticular ascendente originado principalmente na formação reticular do tronco encefálico e é responsável por respostas adaptativas que envolvem integrações sensório-motoras e pelo ciclo sono-vigília. Ao sinalizar a ocorrência de eventos importantes, atua como verdadeiro modulador do tônus da atividade cerebral. ${ }^{6}$ 

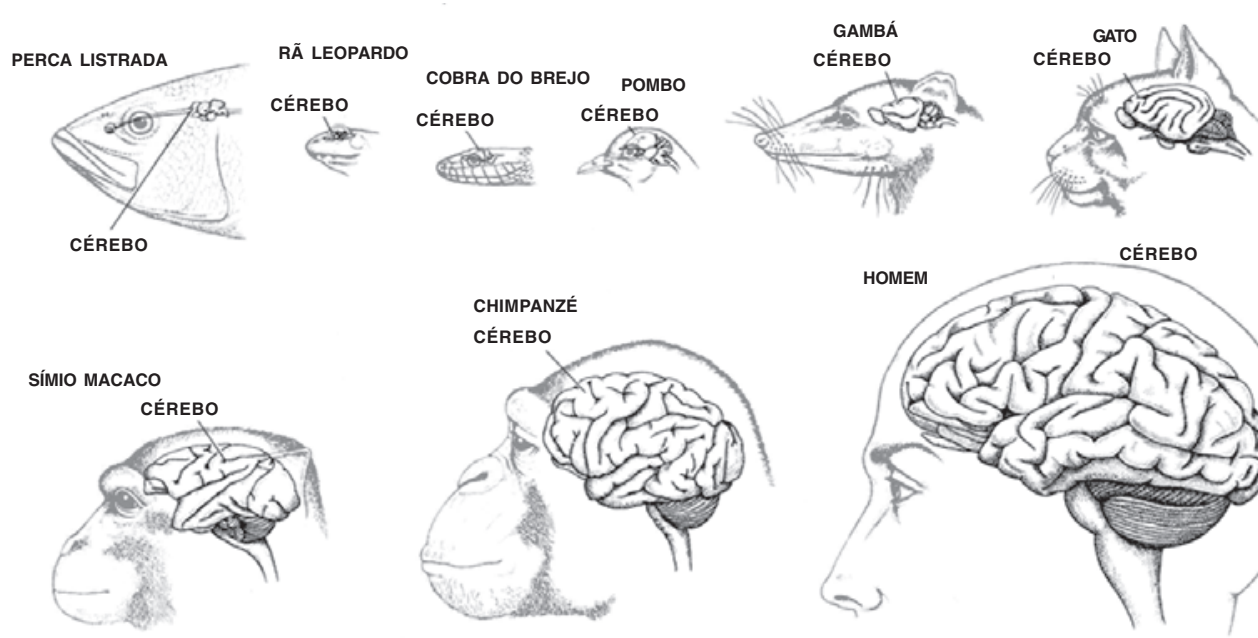

A
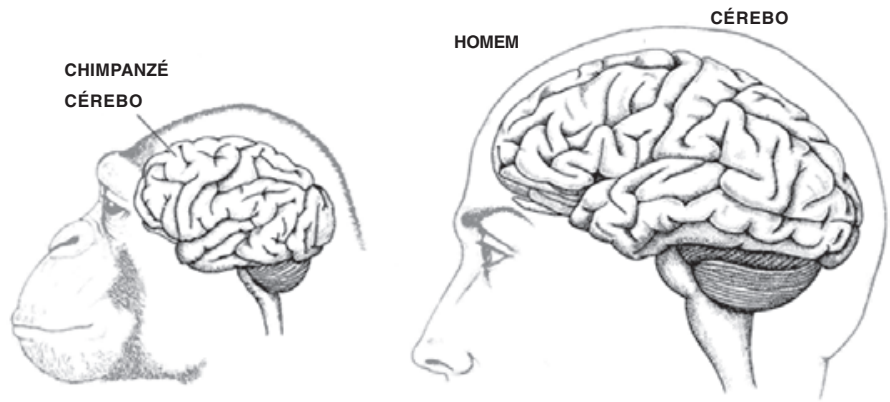

(HUBEL DH, 1979 ${ }^{36-38}$ )

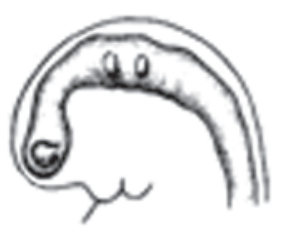

25 dias

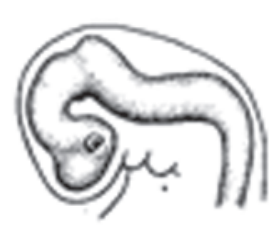

35 dias

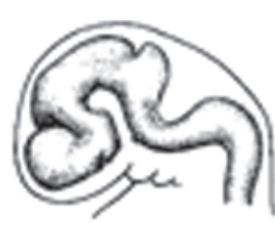

45 dias

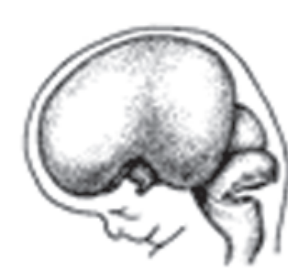

100 dias

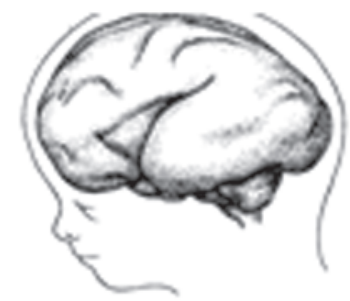

Cinco meses

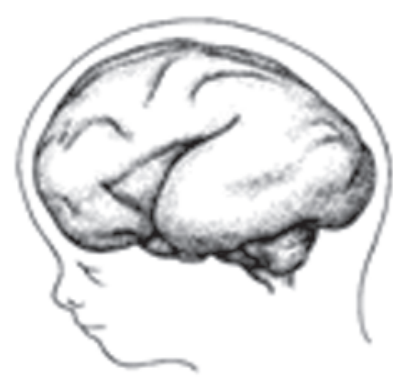

Sete meses

B

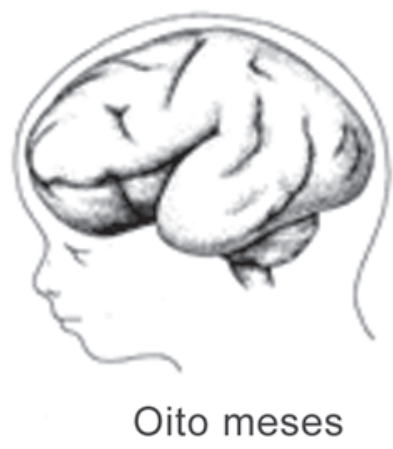

Oito meses

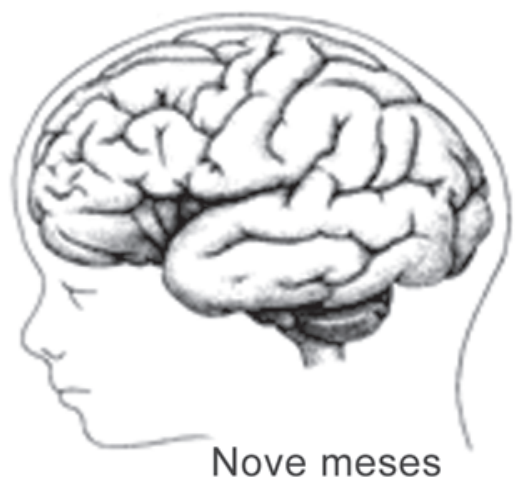

(Cowan WN, 1979 $42 \cdot 44)$

Figura 1 - Evolução (A) filogenética e (B) embriológica e fetal do SNC do ser humano 


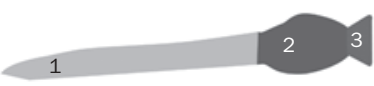

Peixes

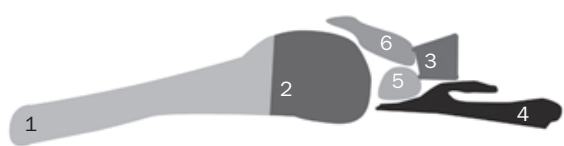

Anfibios / Répteis

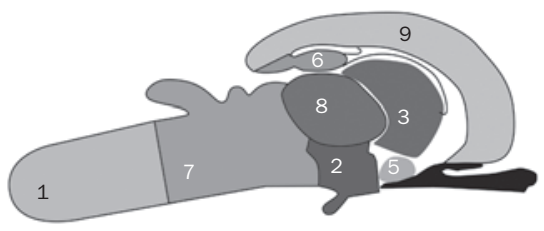

Mamiferos

Figura 2 - Esquema da evolução filogenética do sistema nervoso central (adapt. de Nauta WJH e Feirtag M, 1979,,-45 e baseado em Sarnat HB e Netski MG, 1981')

1: segmento medular; 2: hipotálamo; 3: corpo estriado; 4: estruturas olfatórias; 5: amígdala; 6: hipocampo; 7: tronco encefálico; 8: tálamo; 9: neocórtex

Os sistemas córtico-subcorticais são compostos por circuitos polisinápticos unidirecionais, portanto não recíprocos, que têm como epicentro os gânglios da base que recebem eferências do córtex cerebral e que, após processamento, as devolvem ao córtex por via talâmica e extra-talâmica, além de gerarem eferências também para o hipocampo e cerebelo. Em complemento às suas conhecidas funções motoras usualmente denominadas "extrapiramidais", 13,17-19,21,23 a descrição de que esses circuitos funcionalmente isolados que conectam os gânglios da base ao córtex se organizam em alças unidirecionais, reentrantes e paralelas, feita por Alexander et al. ${ }^{45}$ ao longo da última década, possibilitou vincular a sua atuação também com funções comportamentais da esfera neuropsiquiátrica. 6,25,46-48 Desta forma, enquanto as porções mais posteriores dos gânglios da base (striatum caudal) se relacionam com o planejamento e a execução de atos motores complexos, as suas porções mais anteriores (striatum ventral) se relacionam mais particularmente com rotinas que envolvem atividades cognitivas e padrões de comportamento. ${ }^{25,46-48}$

Para Edelman, ${ }^{6}$ o sistema tálamo-cortical é constituído pelas conexões recíprocas existentes entre o tálamo e o córtex cerebral e também pelas fibras hemisféricas de associação. Portanto, envolve a ativação das áreas especializadas do córtex e das suas áreas e fibras de associação. Enquanto a porção posterior desse sistema se relaciona particularmente com fenômenos de percepção, a sua porção anterior se relaciona principalmente com planejamentos e ações.

É interessante ressaltar que, nesta concepção de Edelman de três conjuntos de circuitos básicos, o sistema límbico não constitui um sistema básico da organização das fibras encefálicas e, sim, um conjunto de estruturas cerebrais mesiais que se dispõem como um círculo em torno do topo do tronco encefálico e que se encontram conectadas aos três sistemas básicos. ${ }^{6}$

No entanto, apesar de todo o atual conhecimento neuroanatômico, neurofisiológico e de áreas correlatas, a fisiologia do psiquismo humano, que tem como cerne a consciência, persiste ainda muito pouco esclarecida.
Tabela 2 - Desenvolvimento filogenético das estruturas encefálicas

\begin{tabular}{lll}
\hline Milhões de anos & \multicolumn{1}{c}{ Espécies } & \multicolumn{1}{c}{ Estruturas nervosas } \\
\hline 435 & Peixes & Medula/Tronco encefálico \\
395 & Anfíbios & Lobo olfatório \\
345 & Insetos / Répteis & Hipocampo/Amígdala \\
230 & Mamíferos & \\
195 & Aves & Sistema límbico/Neocórtex \\
55 & Primatas & \\
24 & Antropóides & \\
5 & Hominídeos & \\
0,01 & Humanosenvolvimento do neocórtex & \\
\hline
\end{tabular}

Adapt. de Sarnat HB e Netski MG, 1981; Gould SJ, $2001^{3}$

Paralelamente às conhecidas controvérsias pertinentes à sua própria conceituação e às dificuldades metodológicas inerentes ao seu estudo, Albright chama a atenção para o fato de que ainda não existe um consenso sobre o que seria uma solução apropriada do esclarecimento do fenômeno da consciência humana. ${ }^{37}$

Em relação à difícil e controversa conceituação de consciência, e tendo em vista o escopo da presente revisão, é particularmente oportuna e apropriada a diferenciação proposta por Edelman entre consciência primária (primary consciousness) e consciência superior (higher-order consciousness).6,49

Para este autor, a consciência primária diz respeito a estar mentalmente consciente do mundo no sentido de poder formular apenas imagens mentais no presente e sem qualquer sentido pessoal de passado e de futuro. Esta se encontra presente nos animais desprovidos de linguagem e de capacidades semânticas. Fenômenos neurofisiológicos de reentrada propiciariam abstrações e comportamentos de adaptação ao meio através da contínua construção de um cenário de "lembranças do presente" (remembered present).6,49

A consciência superior, por sua vez, é a consciência dos seres humanos, composta pelo pensamento no sentido pessoal de considerar passado, presente e futuro, e de não depender obrigatoriamente do envolvimento de receptores e órgãos sensitivos e sensoriais. Edelman enfatiza que a consciência superior se baseia fundamentalmente na ocorrência de percepções diretas apenas do ser humano - que possui as capacidades de linguagem e de descrever a sua vida subjetiva - e que a sua distinção da consciência primária se faz principalmente pela ocorrência de estados fenomenológicos constituídos pela coleção de experiências pessoais objetivas e subjetivas que acompanham quaisquer percepções, a que esse autor denomina qualia. ${ }^{6,49}$

Entre as estruturas nervosas mais particularmente relacionadas com a consciência primária destacam-se o sistema reticular ativador ascendente (que se origina no tronco encefálico), as estruturas límbicas e o hipotálamo, e o sistema tálamo-cortical, enquanto a consciência superior é acrescida e fundamentalmente dependente das áreas cerebrais envolvidas com os processos de linguagem. ${ }^{8,50-52}$ Tendo em vista o desenvolvimento evolutivo dessas estruturas que foi aqui revisado, justifica-se o comentário de Marijuán de que "a consciência se constitui em um fenômeno gradual, com as suas graduações sendo relacionadas com a diferenciação filogenética e ontogenética principalmente do córtex cerebral",53 em concordância com as concepções de Eccles. ${ }^{54}$

O advento da teoria da complexidade e a consideração dos seus conceitos nas áreas biológicas em geral e em neurociências 
em particular, ${ }^{31,50,55-60}$ fez com que a hipótese de que a consciência tenha surgido ao longo da evolução como um fenômeno de emergência viesse a constituir praticamente um consenso entre os estudiosos desse assunto. ${ }^{6,8,31,53,61-65} \mathrm{~A}$ propriedade de emergência inerente aos sistemas complexos não-lineares se caracteriza pelo fato de que a cada nível hierárquico de complexidade podem surgir novas qualidades que não podem ser explicadas tendo-se como base apenas as características dos seus constituintes. Desta forma, com o todo se sobrepujando à soma das suas partes - como exemplos, a umidade surge a partir da interação de moléculas de água; o calor emana do fogo; e sons se originam a partir de vibrações de moléculas de ar. Adotando-se essa concepção, a consciência resultaria de uma particular complexidade estrutural atingida pelo arranjo do emaranhado neuronal ao longo da evolução.

Francis Crick, em seu conhecido livro The astonishing hypothesis, ${ }^{63}$ também aceita a hipótese de emergência e, a partir de um estudo detalhado da função visual em mamíferos e sem se deter em questões de ordem mais conceitual, defende a idéia de que a consciência seja fundamentalmente um produto da circuitaria neural tálamo-cortical. Ele admite que noções mais complexas devam estar mais particularmente relacionadas com determinadas áreas corticais. Nesta direção, Crick enfatiza, em seu texto, a relação da noção de livre arbítrio com a atividade da porção anterior do giro do cíngulo.

Apesar da concordância existente entre os diversos estudiosos a respeito das estruturas nervosas mais envolvidas com a gênese da consciência e com o destaque do papel do sistema tálamo-cortical, pouco se sabe e muito se especula sobre a intimidade dos processos que a viabilizam. ${ }^{15,51,56,64-68}$ Os estudos desses processos abrangem os campos da biologia molecular, da neurocomputação e as mais recentes contribuições da física. ${ }^{53}$ Nessa direção, atualmente destaca-se a complexa proposta de Roger Penrose e de Stuart Hameroff, ${ }^{31,53,69-70}$ que defendem a idéia de que os processos fundamentais que ocorrem ao nível dos microtúbulos do citoesqueleto neuronal ocorrem sob as leis da física quântica, e que através de uma orquestrada sincronização têmporo-espacial otimizam o processamento de informações dirigidas a neurônios piramidais. Como alternativa mais ousada e puramente especulativa, autores como Siler, tendo como base as semelhanças das conformações circulares das estruturas cerebrais profundas e de magnetos e certos tipos de reatores nucleares, sugerem a possibilidade de que alguma forma de energia possa emanar paralelamente e conseqüentemente ao funcionamento da circuitaria neural. ${ }^{71}$

Por outro lado, são interessantes as observações de Albrigth de que todo o estudo científico sobre o processo da vida é atualmente fundamentalmente baseado no que se sabe sobre o DNA e, apesar de que muitas questões pertinentes à consciência possam vir a ser explicadas por estudos dos genes e por diferentes estudos comportamentais, é ainda difícil imaginar como o progresso científico virá a explicar as questões relativas à natureza subjetiva das nossas experiências. ${ }^{37}$

Paralelamente ao notório desenvolvimento das contribuições experimentais em animais, que são limitadas fundamentalmente pelos seus próprios elementos de investigação, os estudos das questões pertinentes à relação mente-cérebro - a partir de dados neurológicos e psicopatológicos no homem, que têm como base alterações quantitativas e qualita-

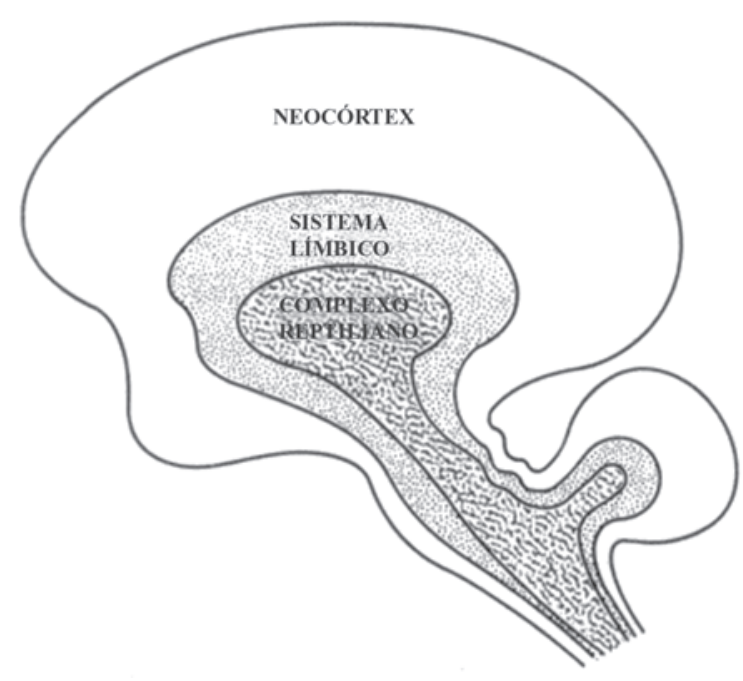

Figura 3 - llustração da concepção do "Encéfalo 3 em 1" (Triune Brain) de MacLean (adapt. de Itzkoff SW, $1983^{9}$ )

tivas da mente humana -, se, por um lado são atualmente limitadas pelos próprios modelos caracterizados pelas doenças e acometimentos existentes, por outro lado se enriquecem progressivamente com o desenvolvimento dos métodos de diagnóstico e avaliação por imagens estruturais e funcionais, entre os quais se destacam as diversas modalidades de imagens obtidas com ressonância magnética e as imagens tomográficas obtidas com emissão de pósitrons ${ }^{* * *}$, que avaliam o metabolismo de diferentes áreas cerebrais. A compreensão das repercussões mentais de tratamentos farmacológicos (interpretação dos fenômenos bioquímicos conseqüentes à ação de drogas) e de tratamentos neurocirúrgicos (ablações e estimulações localizadas realizadas para diferentes fins terapêuticos, psicocirurgias) também contribuem para o estudo desta questão.

Os estudos que seguramente serão realizados no futuro próximo com o emprego de técnicas genéticas, como o implante de células-tronco ${ }^{\dagger+t+}$ para regeneração de áreas nervosas, por um lado acarretarão o levantamento de importantes questões conceituais e éticas e, por outro lado, deverão se constituir em uma nova janela para o estudo da consciência e do psiquismo.

\section{Referências}

1. Sarnat HB, Netsky MG. Evolution of the nervous system. 2nd ed. New York: Oxford University Press; 1981.

2. Darwin C. A origem das espécies. São Paulo: Hemus; 1973.

3. Gould SJ. The book of life. New York: W. W. Norton; 2001.

4. Gould SJ. The structure of the evolutionary theory. Cambridge, MA: Harvard University Press; 2002.

5. Gould SJ. Três aspectos da evolução. In: Brockman J, Matson K, organizadores. As coisas são assim: pequeno repertório científico do mundo que nos cerca. São Paulo: Companhia das Letras; 1997. p. 95-100.

6. Edelman GM, Tononi G. A universe of consciousness: how matter becomes imagination. New York: Basic Books; 2000.

7. Allman JM. Evolving brains. New York: Scientific American Library; 2000. 224 p.

$* * * *$ Do inglês: Positron Emisson Tomography (PET Scan)

${ }^{\dagger+\dagger}$ Do inglês: Stem Cells 
8. Kayzer W. Maravilhosa obra do acaso. Rio de Janeiro: Nova Fronteira; 1995. $166 \mathrm{p}$.

9. Itzkoff SW. The form of man. Ashfield, MA: Paideia Publishers; 1983. 336 p.

10. Haeckel E. The evolution of man. London: Watts; 1905. Apud Gould SJ. Ontogeny and phylogeny. Cambridge, MA: Harvard University Press; 1977.

11. Gould SJ. Ontogeny and phylogeny. Cambridge, MA: Harvard University Press; 1977.

12. Gibor A. Conditions for life: readings from American Scientific. San Francisco: W. H. Freeman; 1976.

13. Squire LR, Bloom FE, McConnell SK, Roberts JL, Spitzer NC Zigmond MJ. Fundamental neuroscience. 2nd ed. Amsterdam: Elsevier Academic Press; 2003.

14. Machado A. Neuroanatomia funcional. 32a ed. São Paulo: Atheneu; 1993.

15. Morowitz HJ. The epistemic paradox of mind and matter. In: Marijuan PC, editor. Cajal and consciousness: scientific approaches to consciousness on the centennial of Ramón y Cajal's Textura. Ann N Y Acad Sci. 2001;929:50-4. New York: New York Academy of Sciences.

16. Magoun HW. El cerebro despierto. México DF: La Prensa Medica Mexicana; 1968.

17. Brodal A. Neurological anatomy in relation to clinical medicine. 3rd ed. New York: Oxford University Press; 1981.

18. Williams PL, Warwick R, editors. Gray's anatomy. 36th ed. Philadelphia, PA: Saunders; 1980. 753 p.

19. Ferreira AG. Dicionário de latim-português. Porto: Porto Editora; 1966. 1240 p.

20. Duvernoy HM. The human hippocampus. 2nd ed. Berlin: SpringerVerlag; 1998.

21. Heimer L. The human brain and spinal cord: functiona neuroanatomy and dissection guide. 2nd ed. New York: SpringerVerlag; 1995

22. Lockard I. Desk reference for neuroanatomy: a guide to essential terms. New York: Springer-Verlag; 1977.

23. Kandel ER, Schwartz JH, Jessell TM, editors. Principles of neural science. 3rd ed. New York: Elsevier; 1991.

24. Martin JH. Neuroanatomy, text and atlas. 2nd ed. Stamford, CT: Appleton and Lange; 1996.

25. Heimer L. A new anatomical framework for neuropsychiatric disorders and drug abuse. Am J Psychiatry. 2003;160:1726-39.

26. Nieuwenhuys R, Voogt J, Van Huijzen C, Lange W. The human central nervous system. 3rd ed. Berlin: Springer-Verlag; 1988.

27. Penfield WG, Rasmussen TB. The cerebral cortex of man. New York: The MacMillan; 1952

28. Brodmann K. Verleichende lokalisations lehre der Grosshirnrinde in ihren Prinzipien dar gestellt auf Grund des Zellenbanes. Leipzig, DE: J. A. Barth; 1909 (reprinted). 1925;12. 324p. apud Penfield W. Cerebral cortex of man. New York: Mac Millan; 1952.

29. Ono M, Kubik S, Abernathey CD. Atlas of cerebral sulci. Stuttgart: Thieme-Verlag; 1990.

30. Yasargil MG. Microneurosurgery. Stuttgart: Georg Thieme; 1994. v.IVa.

31. Trefil J. Somos diferentes? Um cientista explora a inteligência ímpar da mente humana. Rio de Janeiro: Rocco; 1999.

32. Donald M. Origins of the modern mind: three stages in the evolution of culture and cognition. Cambridge, MA: Harvard University Press; 1991

33. The first men. The emergence of Man Series. Nederland: Time-Life International; 1975.

34. Brenot P. As origens. Lisboa: Editorial Presença; 1992.

35. Pinker S. The language instinct. New York: William Morrow; 1994 Apud Trefil J. Somos diferentes? Um cientista explora a inteligência ímpar da mente humana. Rio de Janeiro: Rocco; 1999.

36. Hubel DH. The brain. In: The brain: a scientific american book. San Francisco: Scientific American, W. H. Freeman; 1979. p. 4-11.

37. Albright TD, Jessell TM, Kandel ER, Posner MI. Progress in the neural sciences in the century after Cajal (and the mysteries that remain). In: Marijuan PC, editor. Cajal and consciousness: scientific approaches to consciousness on the centennial of Ramón y Cajal's Textura. Ann N Y Acad Sci. 2001;929:11-40.
38. Broca P. Remarques sur le siège de la facultè du langage articulé: suiries d'une observation d'aphémie (perte de la perole). Bull Soc d'Anth (Paris). 1861;6:330-57/397-407. Apud Finger S. Origins of neuroscience: a history of exploration into brain function. New York: Oxford University Press; 1994. 462 p.

39. Finger $\mathrm{S}$. Origins of neuroscience: a history of exploration into brain function. New York: Oxford University Press; 1994. 462 p.

40. Chomsky N. Novos horizontes no estudo da linguagem e da mente. São Paulo: Editora da UNESP; 2005. 364 p.

41. Burke J, Ornstein R. O presente do fazedor de machados. Rio de Janeiro: Bertrand Brasil; 1995.

42. Cowan WM. The development of the brain. In: The brain. A scientific American book. San Francisco: W. H. Freeman; 1979. p. 57-67.

43. Nauta WJH, Feirtag M. The organization of the brain. In: The brain. A Scientific American Book. San Francisco: W. H. Freeman; 1979. p. 39-53.

44. McLean PD. The triune brain in evolution: role in paleocerebral functions. New York: Plenum; 1990. Apud Pinker S. How the mind works. New York: W. W. Norton; 1997

45. Alexander GE, DeLong MR, Strick PL. Parallel organization of functionally segregated circuits linking basal ganglia and cortex. Annu Rev Neurosci. 1986;9:357-81. Apud Heimer L. A new anatomical framework for neuropsychiatric disorders and drug abuse. Am J Psychiatry. 2003;160(10):1726-39. Erratum in: Am J Psychiatry. 2003;160(12):2258.

46. Mega MS, Cummings JL. Frontal-subcortical circuits and neuropsychiatric disorders. J Neuropsychiatry. 1994;6:358-70. Apud Heimer L. A new anatomical framework for neuropsychiatric disorders and drug abuse. Am J Psychiatry. 2003;160(10):172639. Erratum in: Am J Psychiatry. 2003;160(12):2258.

47. Mc Ginty JF, editor. Advancing from the ventral striatum to the extended amygdala: implications for neuropsychiatry and drug abuse. Ann N Y Acd Sci. 1999;877.

48. Mello LE, Villares J. Neuropsychiatry of the basal ganglia. Psychiatric Clin North Am. 1997;20(4):691-91.

49. Edelman G. Consciousness: the remembered present. In: Marijuan PC, editor. Cajal and consciousness: scientific approaches to consciousness on the centennial of Ramón y Cajal's Textura. Ann N Y Acad Sci. 2001;929:111-22.

50. Arecchi FT. Complexity, complex systems, and adaptation. In: Rossi C, Bastianoni S, Donati A, Marchettini N, editors. Tempos in science and nature: structures, relations, and complexity. Ann N Y Acad Sci. 1999;879:45-62.

51. Pinker S. How the mind works. New York: W. W. Norton; 1997

52. Ramachandran VS. A brief tour of human consciousness: from impostor poodles to purple numbers. New York: Pi Press; 2004-5.

53. Marijuan PC. Cajal and consciousness: introduction. In: Marijuan PC, editor. Cajal and consciousness: scientific approaches to consciousness on the centennial of Ramón y Cajal's Textura. Ann N Y Acad Sci. 2001;929:1-10.

54. Popper KR, Eccles JC. The self and its brain: an argument for interactionism. Berlin: Springer-Verlag; 1977

55. Rossi C, Tiezzi E. Preface. In: Rossi C, Bastianoni S, Donati A, Marchettini N, editors. Tempos in science and nature: structures, relations, and complexity. Ann N Y Acad Sci. 1955;879.

56. Bocchi G, Ceruti M. Complexity and the Unfinished nature of human evolution. In: Rossi C, Bastianoni S, Donati A, Marchettini N, editors. Tempos in science and nature: structures, relations, and complexity. Ann N Y Acad Sci. 1999;879:63-74.

57. Chandler JLR. Complexity VII: composing natural science from natural numbers, natural kinds, and natural affinities. In: Rossi C, Bastianoni S, Donati A, Marchettini N, editors. Tempos in science and nature: structures, relations, and complexity. Ann N Y Acad Sci. 1999;879:75-86.

58. Jacob F. Complexity and tinkering. In: Marijuan PC, editor. Cajal and consciousness: scientific approaches to consciousness on the centennial of Ramón y Cajal's Textura. Ann N Y Acad Sci. 2001;929:71-3.

59. Lorenz EN. A essência do caos. Brasília: Editora UnB;1996.

60. Morin E. Organization and complexity. In: Rossi C, Bastianoni S, Donati A, Marchettini N, editors. Tempos in science and nature: structures, relations, and complexity. Ann N Y Acad Sci. 1999;879:115-21. 
61. Freeman A, editor. The emergence of consciousness. Charlottesville, VA: Imprint Academic; 2001.

62. Gell-Mann M. Consciousness, reduction, and emergence: some remarks. In: Marijuan PC, editor. Cajal and consciousness: scientific approaches to consciousness on the centennial of Ramón y Cajal's Textura. Ann N Y Acad Sci. 2001;929:41-9.

63. Crick F. The astonishing hypothesis: the scientific search for the soul. New York: Simon and Schuster; 1995.

64. LeDoux J. Synaptic self: how our brains become who we are. New York: Penguin Book; 2002. 467 p.

65. Penrose R. The large, the small and the human mind. Cambridge, MA: Press Syndicate of the University of Cambridge; 1997.

66. Arbib MA. Co-evolution of human consciousness and language. In: Marijuan PC, editor. Cajal and consciousness: scientific approaches to consciousness on the centennial of Ramón y Cajal's Textura. Ann N Y Acad Sci. 2001;929:195-220.

67. Llinas R, Ribary U. Consciousness and the brain: the thalamocortical dialogue in health and disease. In: Marijuan PC, editor. Cajal and consciousness: scientific approaches to consciousness on the centennial of Ramón y Cajal's Textura. Ann N Y Acad Sci. 2001;929:166-75.

68. Margulis L. the conscious cell. In: Marijuan PC, editor. Cajal and consciousness: scientific approaches to consciousness on the centennial of Ramón y Cajal's Textura. Ann N Y Acad Sci. 2001;929:55-70.

69. Hameroff S. Consciousness, the brain, and spacetime geometry. In: Marijuán PC, editor. Cajal and consciousness: scientific approaches to consciousness on the centennial of Ramón y Cajal's Textura. Ann N Y Acad Sci. 2001;929:74-104.

70. Penrose R. Consciousness, the brain, and spacetime geometry: an addendum - some new developments on the Orch OR model for consciousness. In: Marijuán PC, editor. Cajal and consciousness: scientific approaches to consciousness on the centennial of Ramón y Cajal's Textura. Ann N Y Acad Sci. 2001;929:105-10.

71. Siler T. Breaking the mind barrier: the artscience of neurocosmology. New York: Simon and Schuster; 1990. 